\title{
DETERMINATION OF FREE DOXYCYCLINE CONCENTRATIONS IN THE PLASMA AND MILK OF SHEEP AND IN THE PLASMA OF RABBITS BY USING THE HPLC METHOD
}

\author{
Rositsa Mileva \\ Department of Pharmacology, Physiology of Animals and Physiological Chemistry, \\ Faculty of Veterinary Medicine, Trakia University, 6015 Stara Zagora, Bulgaria
}

Received 15 November 2018; Received in revised form 11 March 2019; Accepted 26 March 2019

\begin{abstract}
A fast and sensitive HPLC method was validated in order to analyze doxycycline in plasma and milk of sheep and in plasma of rabbits. The samples were processed with trifluoroacetic acid (TFA). After the centrifugation step, a supernatant containing extracted doxycycline and internal standard oxytetracycline was injected into the HPLC system with PDA detection. The method showed linearity in the range of $0.125-2.5 \mu \mathrm{g} / \mathrm{mL}$ for ovine plasma, $0.125-5.0 \mu \mathrm{g} / \mathrm{mL}$ for ovine milk, and $0.125-1 \mu \mathrm{g} / \mathrm{mL}$ for rabbit plasma. The inter-assay precision varied between $5.69-13.55 \%$. Values for intraassay precision were between $0.62-8.67 \%$. Accuracy was higher than $90 \%$ in all of the tested concentrations in the three types of biological matrices. The mean extraction recovery was higher than $90 \%$ for all matrices. In order to handle only with free drug concentrations, microfiltration of standard solutions with low $(0.25 \mathrm{mg} / \mathrm{mL})$, medium $(0.5 \mathrm{mg} / \mathrm{mL})$ and high $(1.0 \mathrm{mg} / \mathrm{mL})$ concentration was performed. A percentage for correction of the quantified doxycycline was calculated. The most significant adjustments should be made at the low concentrations. The correction for rabbit plasma is $24.63 \pm 5.03 \%$, for ovine plasma is $20.10 \pm 8.01 \%$ and for milk $-16.68 \pm 0.04 \%$. This method can be used for routine determination of doxycycline concentrations for pharmacokinetic studies and further dosage adjustment.
\end{abstract}

Key words: free doxycycline concentration, HPLC analysis, sheep plasma and milk, rabbit

\section{INTRODUCTION}

Tetracyclines have been widely used in veterinary medicine for treatment of farm and pet animals. This is mainly due to their broad spectrum of activity, high efficacy, and relatively low risk of adverse effects. Doxycycline is a second generation semisynthetic tetracycline antibiotic with an activity against $\mathrm{Gr}^{+}$and $\mathrm{Gr}^{-}$aerobic and anaerobic bacteria, including some intracellular pathogens (1). Its bacteriostatic activity is due to the blocking of the $30 \mathrm{~S}$ ribosomal subunit and thereby the microbial protein synthesis (1). In practice, it is mainly used

Corresponding author: Rositsa Zh. Mileva, MSc, DVM

E-mail address: rossi bu@abv.bg

Present address: Department of Pharmacology, Physiology of Animals

and Physiological Chemistry, Faculty of Veterinary Medicine, Trakia

University, 6015 Stara Zagora, Bulgaria

Phone: ++0035942699 552; ++00359 883331406

Copyright: (C) 2019 Mileva R. This is an open-access article published under the terms of the Creative Commons Attribution License which permits unrestricted use, distribution, and reproduction in any medium, provided the original author and source are credited.

Competing Interests: The authors have declared that no competing interests exist.

Available Online First: 9 June 2019

Published on: 15 October 2019

https://doi.org/10.2478/macvetrev-2019-0016 as doxycycline hyclate. Doxycycline has advantages over other tetracyclines. It penetrates well in tissues, has a higher bioavailability after oral administration, better antimicrobial activity, and lower affinity for $\mathrm{Ca}^{2+}$ (2). Doxycycline has the longest elimination half-life compared to other tetracyclines, as well as the highest protein binding (3). Therefore, it is retained in the body longer than the other antibiotics from the group. Doxycycline is more stable in water solution, which makes it suitable for administration with the drinking water (4).

The presence of antimicrobial resistance represents a significant problem in veterinary and human medicine. Resistance to doxycycline has been observed in some microorganisms such as Staphylococcus aureus, Enterococcus spp., Salmonella spp., Pasteurella spp. (5, 6, 7). In order to limit the selection and spreading of resistance, precise choice of antibiotic treatment and evidenced based adjustment of the dosage regimen of doxycycline are needed. For this purpose, not only MIC value determination is required, but also knowledge of accurate in vivo free drug 
concentrations. Only free, protein unbound doxycycline levels are effective concentrations in the body and the calculation of the pharmacokinetic parameters should be based on the free plasma concentrations found in the biological fluids. A simulation, predicting mean plasma concentrations in dogs, shows that the unbound level of the drug is remarkably lower than the total plasma concentrations, which influences the success of the therapy (8). So far, a lot of the pharmacokinetic studies have not been corrected for binding to plasma or milk proteins $(9,10)$. Information about free doxycycline levels in small ruminants is needed because of its importance for control of bacterial infections and because it was increasingly common in last years tick-borne rickettsioses. The data about doxycycline in small ruminants and rabbits is insufficient. It is not clear whether the methods used in other animal species are applicable, and whether those methods exclude utmost the bound part of the drug (10).

The aim of the current study was firstly to validate an HPLC method for determination of doxycycline concentrations in ovine plasma and milk, and in rabbit plasma, which would permit the analysis of a large number of samples for clinical studies and settings. The second goal was to purify the samples and to determine the eventual fraction which is bound to blood proteins. The calculated percentage for correction of the quantified amounts can be used in pharmacokinetic studies and future adjustments of dosing regimen.

\section{MATERIAL AND METHODS}

\section{Chemicals and reagents}

The reagents used in the current study were HPLC grade. Doxycycline hyclate with purity $\geq$ 98\% (TLC, Sigma D9891, Lot\#/BCBF9827V) and oxytetracycline hydrochloride $\geq 95 \%$ crystalline (Sigma, HPLC, 05875, Lot\#BCBG9599V), were used as reference compounds and for preparation of standard solutions. Acetonitrile CHROMASOLV®, HPLC grade, $\geq 99.9 \%$ purity (Sigma-Aldrich,), methanol $\geq 99.8 \%$ purity HiPerSolv CHROMANORM ${ }^{\circledR}$ for HPLC isocratic grade (VWR BDH PROLABO ${ }^{2}$ ), oxalic acid $98 \%$ purity (Sigma Chemical Co., St. Louis, MO, USA), ethylenediaminetetraacetic acid disodium salt dihydrate $99.0-101.0 \%$ $\left(\mathrm{Na}_{2} \mathrm{H}_{2}\right.$ EDTA $x \quad 2 \mathrm{H}_{2} \mathrm{O}$, Sigma-Aldrich $)$ and trifluoroacetic acid ReagentPlus ${ }^{\circledR}, 99 \%$ purity (Sigma-Aldrich) were used for sample preparation and for the mobile phase.

\section{Standard solutions}

Stock solutions of doxycycline hyclate and oxytetracycline hydrochloride were prepared in deionized water at concentration of $10 \mathrm{mg} / \mathrm{mL}$. They were used within one month. Oxytetracycline solution was used as an internal standard (IS) at concentration of $11 \mu \mathrm{g} / \mathrm{mL}$. Standard working solutions were freshly prepared on the day of analysis. They were obtained by dilution of the stock solution of doxycycline hyclate with drug-free ovine plasma or milk, and with drug-free rabbit plasma at concentrations of 5, $2.5,1,0.5,0.25$ and $0.125 \mu \mathrm{g} / \mathrm{mL}$. Blood samples were obtained from lactating sheep $(\mathrm{n}=6)$ and rabbits $(\mathrm{n}=7)$ according to the Bulgarian legislation for welfare of experimental animals (Regulation No 20/09.11.2012). Standard solutions were prepared in deionized water at the same concentration range as described above for plasma and milk.

\section{Extraction procedure}

Plasma samples $(400 \mu \mathrm{l})$ were spiked with $40 \mu \mathrm{l}$ IS and $52 \mu 1$ trifluoroacetic acid (TFA). They were vortexed for $1 \mathrm{~min}$ and centrifuged for $10 \mathrm{~min}$ at $10800 \mathrm{~g}$ at $22^{\circ} \mathrm{C}$. The supernatant was carefully placed in HPLC vials and $20 \mu \mathrm{l}$ of each concentration were injected into the HPLC system. Milk samples $(900 \mu \mathrm{l})$ were mixed with $90 \mu \mathrm{l}$ IS and $117 \mu \mathrm{l}$ TFA. After vortexing for $1 \mathrm{~min}$ and centrifugation for $10 \mathrm{~min}$ at $10800 \mathrm{~g}$ at $22^{\circ} \mathrm{C}$, the supernatant was transferred to another tube. These samples were centrifuged again for $5 \mathrm{~min}$ at $10800 \mathrm{~g}$ at $22^{\circ} \mathrm{C}$ and then filtered through standard filter paper (grade 600 pore size $10-20 \mathrm{~mm}$, Fiorony Filters). The filtrate was placed in a vial and $20 \mu \mathrm{l}$ of each concentration were injected into the HPLC system.

\section{Protein purification}

Standard solutions of doxycycline in ovine plasma and milk and in rabbit plasma with low $(0.25 \mu \mathrm{g} / \mathrm{mL})$, medium $(0.5 \mu \mathrm{g} / \mathrm{mL})$, and high $(1.0$ $\mu \mathrm{g} / \mathrm{mL}$ ) concentrations were further purified, before injecting them into the HPLC. For this purpose Ultrafree $\mathbb{B}$ - MC Centrifugal Filters with hydrophilic PTFE membrane and $0.45 \mu \mathrm{m}$ pore size were used. The purification step was performed for each concentration in each matrix in triplicate. The samples were centrifuged for $4 \mathrm{~min}$ at $10800 \mathrm{~g}$ at $22^{\circ} \mathrm{C} .20 \mu \mathrm{l}$ of each filtrate were injected three times into the HPLC system. The percentage for protein binding was calculated according to manufacturer instructions and the following equation:

$$
\%=[(\text { conc NF-conc F }) / \text { conc NF }]^{* 100}
$$


where conc NF is the measured concentration before microfiltration and conc $\mathrm{F}$ is the concentration after microfiltration.

\section{HPLC analysis}

All analysis was performed on a HPLC system comprising Hypersil Gold column $(5 \mu \mathrm{M}, 150 \times 4.6 \mathrm{~mm})$, Surveyor LC Pump Plus, PDA detector Surveyor and a Surveyor Auto sampler Plus (Thermo FisherScientific Inc., USA). The column was used at room temperature. The mobile phase consisted of acetonitrile, methanol, $0.02 \mathrm{M}$ oxalic acid and $0.02 \mathrm{M} \mathrm{Na}_{2} \mathrm{H}_{2}$ EDTA $\mathrm{x}$ $2 \mathrm{H}_{2} \mathrm{O}(20: 15: 64: 1, \mathrm{v} / \mathrm{v} / \mathrm{v} / \mathrm{v})$. The flow rate was $1.0 \mathrm{~mL} / \mathrm{min}$. The detection wavelength was set at $345 \mathrm{~nm}$. Peak area integrations were measured by the ChromQuest Chromatography Data System (Thermo Fisher Scientific Inc., USA).

\section{Calibration curve}

Standard solutions were prepared and analyzed as described above. The peak area ratio of doxycycline to the IS was plotted against the spiked concentrations to obtain the calibration curve. The curves were characterized by linear regression. To test the validity of the linear regression model, a statistical test for lack-of-fit was performed (Statistica for Windows 7, Stat Soft Inc., USA). Regression coefficient, slope and intercept were calculated.

\section{Limit of detection (LOD) and Limit of quantitation (LOQ)}

The LOD of doxycycline in plasma and milk samples was determined as the lowest amount in a sample that can be detected but not necessarily quantified (11). The LOQ is defined as the lowest amount of the analyte in the samples that can be determined with acceptable precision and accuracy (11). Calculations for the LODs were based on the standard deviation (SD) of y-intersepts of the regression lines and the slope (S), using the following equation: $\mathrm{LOD}=3.3(\mathrm{SD} / \mathrm{S})$. The LOQs were calculated by the equation $\mathrm{LOQ}=10(\mathrm{SD} / \mathrm{S})(11)$.

\section{Extraction recovery}

The recovery of doxycycline was determined by comparing its concentration in standards, prepared in plasma or milk after extraction, to those prepared in deionized water. The analyses were performed on low $(0.25 \mu \mathrm{g} / \mathrm{mL})$, medium $(0.5 \mu \mathrm{g} / \mathrm{mL})$ and high concentrations $(1.0 \mu \mathrm{g} / \mathrm{mL})$.

\section{Accuracy and precision}

Inter-assay and intra-assay precision of the method was assessed. The different concentrations of doxycycline in each biological matrix were analyzed on the same day in triplicate. The procedure was repeated also on different days $(n=3)$ (11). The accuracy was determined by comparison of the value of measured concentration to its true value (11).

\section{Interferences}

The analysis of blank ovine plasma and milk, and rabbit plasma, obtained from different individuals did not show interfering peaks at the retention time of doxycycline. The analysis of standard working solutions of doxycycline in plasma (from sheep and rabbits) and in ovine milk showed no interfering peaks at the retention time of doxycycline.

\section{RESULTS}

The parameters of standard curves for doxycycline are shown in Table 1. The goodnessof-fit of linear regression model for standard curves was evaluated according to the value of $r^{2}$ (coefficient of determination).

It varied between 0.9923 and 0.9989 for the three different matrices. Additionally, a test for lack of fit was performed. It showed that the standard curves were linear in the range of $0.125-2.5 \mu \mathrm{g} / \mathrm{mL}$ for ovine plasma $(\mathrm{p}=0.99), 0.125-5.0 \mu \mathrm{g} / \mathrm{mL}$ for ovine milk $(\mathrm{p}=0.99)$, and $0.125-1.0 \mu \mathrm{g} / \mathrm{mL}$ for rabbit plasma $(\mathrm{p}=0.08)$. Interfering peaks did not appear at the retention times of the investigated compounds: doxycycline and the internal standard

Table 1. Retention time, linearity of standard curves, limit of detection (LOD) and limit of quantification (LOQ) of doxycycline determined by HPLC Method with PDA detector

\begin{tabular}{lcccc}
\hline \multicolumn{1}{c}{ Biological matrix } & Retention time (min) & Linearity $\left(\mathbf{r}^{2}\right)$ & $\begin{array}{c}\text { LOD } \\
\boldsymbol{\mu g} / \mathbf{m L}\end{array}$ & $\begin{array}{c}\text { LOQ } \\
\mathbf{M g} / \mathbf{m L}\end{array}$ \\
\hline Ovine plasma & 5.69 & 0.9923 & 0.09 & 0.26 \\
Ovine milk & 5.75 & 0.9989 & 0.06 & 0.18 \\
Rabbit plasma & 5.66 & 0.9981 & 0.05 & 0.15 \\
\hline
\end{tabular}




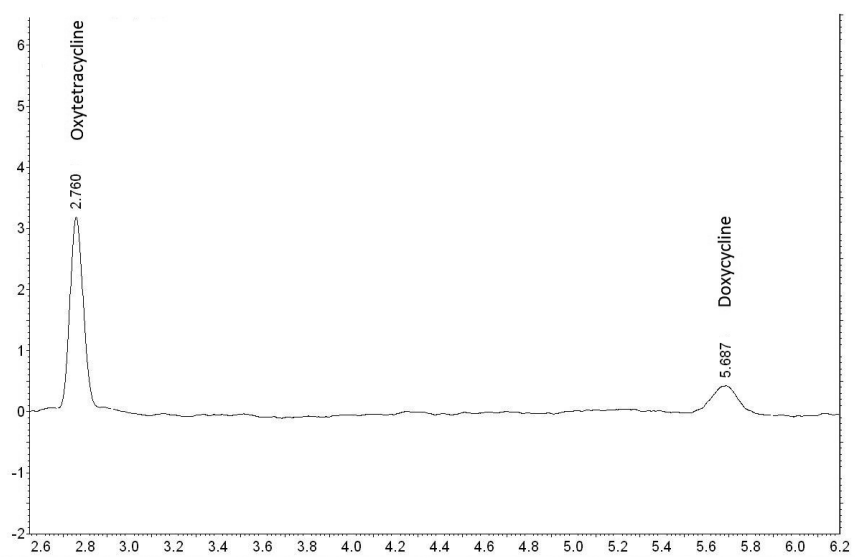

Figure 1. HPLC chromatogram of doxycycline in ovine plasma spiked with $1 \mu \mathrm{g} / \mathrm{mL}$ doxycycline hyclate and $11 \mu \mathrm{g} / \mathrm{mL}$ oxytetracycline hydrochloride (IS). The detection wavelength was set at $345 \mathrm{~nm}$

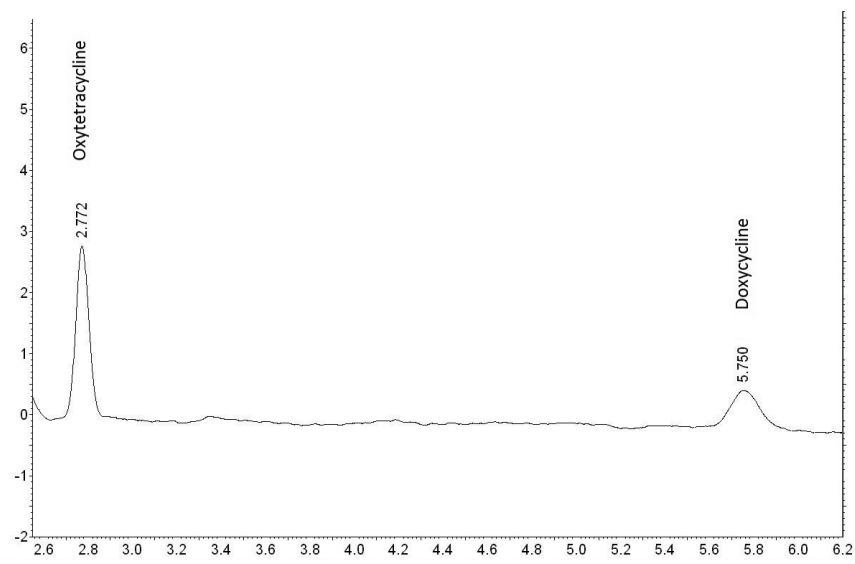

Figure 2. HPLC chromatogram of doxycycline in ovine milk spiked with $1 \mu \mathrm{g} / \mathrm{mL}$ doxycycline hyclate and $11 \mu \mathrm{g} / \mathrm{mL}$ oxytetracycline hydrochloride (IS). The detection wavelength was set at $345 \mathrm{~nm}$

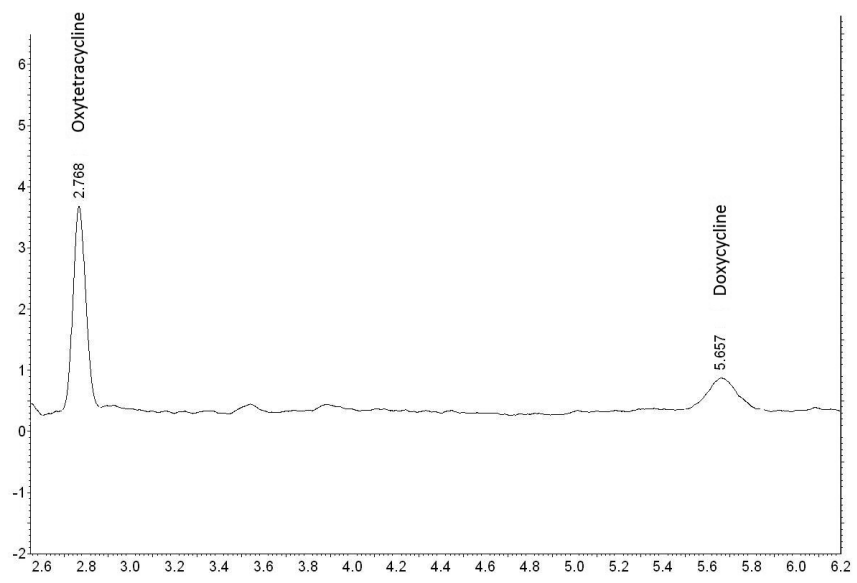

Figure 3. HPLC Chromatogram of doxycycline in rabbit plasma spiked with $1 \mu \mathrm{g} / \mathrm{mL}$ Doxycycline hyclate and $11 \mu \mathrm{g} / \mathrm{mL}$ oxytetracycline hydrochloride (IS). The detection wavelength was set at $345 \mathrm{~nm}$ 
Table 2. Data for accuracy, recovery and precision for HPLC method with PDA detection for determination of doxycycline in different biological matrices. Each concentration was run three times daily, on three different days

\begin{tabular}{|c|c|c|c|c|c|c|}
\hline \multirow{2}{*}{$\begin{array}{l}\text { Biological } \\
\text { matrix }\end{array}$} & \multicolumn{2}{|c|}{ Doxycycline $(\mu \mathrm{g} / \mathrm{mL} \pm \mathrm{SD})$} & \multirow{2}{*}{$\begin{array}{c}\text { Accuracy } \\
(\%)\end{array}$} & \multirow{2}{*}{$\begin{array}{l}\text { Recovery } \\
(\% \pm \text { SD) }\end{array}$} & \multicolumn{2}{|c|}{ Precision (RSD \%) } \\
\hline & Added & Found & & & Intra-Assay & Inter-Assay \\
\hline \multirow{3}{*}{$\begin{array}{c}\text { Ovine } \\
\text { plasma }\end{array}$} & 0.25 & $0.24 \pm 0.02$ & 96.01 & $72.24 \pm 8.67$ & 7.56 & 11.90 \\
\hline & 0.5 & $0.46 \pm 0.02$ & 92.07 & $93.56 \pm 10.51$ & 3.50 & 9.40 \\
\hline & 1.0 & $0.97 \pm 0.02$ & 97.44 & $107.23 \pm 5.71$ & 5.66 & 12.02 \\
\hline \multirow{3}{*}{$\begin{array}{c}\text { Ovine } \\
\text { milk }\end{array}$} & 0.25 & $0.27 \pm 0.02$ & 107.70 & $83.73 \pm 4.64$ & 2.46 & 8.83 \\
\hline & 0.5 & $0.50 * \pm 0.07$ & 99.77 & $87.07 \pm 6.49$ & 8.67 & 5.69 \\
\hline & 1.0 & $0.95 \pm 0.05$ & 95.41 & $102.67 \pm 6.85$ & 0.68 & 6.01 \\
\hline \multirow{3}{*}{$\begin{array}{l}\text { Rabbit } \\
\text { plasma }\end{array}$} & 0.25 & $0.26 \pm 0.02$ & 105.22 & $83.77 \pm 6.90$ & 7.51 & 13.55 \\
\hline & 0.5 & $0.49 \pm 0.03$ & 98.34 & $93.22 \pm 5.44$ & 6.52 & 6.67 \\
\hline & 1.0 & $0.91 \pm 0.07$ & 90.55 & $90.56 \pm 7.11$ & 0.62 & 11.23 \\
\hline
\end{tabular}

* The exact value is $0.4988 \mu \mathrm{g} / \mathrm{mL}$

oxytetracycline. The run times were less than 7 minutes and allowed a high sample throughput on a daily basis. Representative chromatograms are shown in Fig. 1 for ovine plasma, in Fig. 2 for ovine milk. A chromatogram for rabbit plasma is shown in Fig. 3.

Table 2 presents the results for the accuracy and precision. The mean values of accuracy for doxycycline in ovine plasma were between 92.07 and $97.44 \%$, and for rabbit plasma they were in the range of $90.55-105.22 \%$. The same values for ovine milk were between 95.41 and $107.70 \%$. The intra-day precision of the ovine and rabbit plasma was lower than $8 \%$, and lower than $9 \%$ for the ovine milk. The values for inter-day precision were with minor variations for the ovine milk lower than $9 \%$ and for ovine and rabbit plasma lower than $13 \%$ and $14 \%$, respectively. Mean values of recovery for the tested concentrations were close to $90 \%$ (Table 2).

Sample processing was performed by using ultrafree microfilters. The additional step was done in order to further purify the samples and to determine the free doxycycline concentration in the range of concentrations that can be found in vivo. After microfiltration, a percentage for correction of the quantified doxycycline in standard solutions in low, medium, and high concentrations was calculated. The results are shown in Table 3. It appears that even after protein precipitation with TFA, a small percentage of bound doxycycline remains in the sample. The highest correction is necessary for the lowest concentrations in the three biological matrices.

Table 3. Percentage bound doxycycline at the tested concentrations in ovine plasma and milk and in rabbit plasma after protein precipitation with TFA (ReagentPlus ${ }^{\circledR}, 99 \%$ purity (Sigma-Aldrich) and sample purification with Ultrafree ${ }^{\circledR}$ - MC Centrifugal Filters (PTFE membrane, pore size $0.45 \mu \mathrm{m}$ )

\begin{tabular}{ccc}
\hline Biological matrix & $\begin{array}{c}\text { Concentration }(\mathbf{m g} / \mathbf{m L}) \text { of the } \\
\text { standard solution }(\mathbf{N}=\mathbf{3})\end{array}$ & $\begin{array}{c}\text { Mean \% } \pm \text { SD \% } \\
\text { for correction of doxycycline concentrations after } \\
\text { protein purification }\end{array}$ \\
\hline Ovine plasma & 0.25 & $20.10 \pm 8.01$ \\
Ovine milk & 0.5 & $10.63 \pm 5.10$ \\
& 1.0 & $4.88 \pm 7.57$ \\
\hline \multirow{2}{*}{ Rabbit plasma } & 0.25 & $16.68 \pm 0.04$ \\
& 0.5 & $4.00 \pm 0.01$ \\
& 1.0 & $8.83 \pm 0.06$ \\
\hline
\end{tabular}




\section{DISCUSSION}

The developed HPLC method is intended for future pharmacokinetic studies and dosing regimen adjustments. It allows detection of doxycycline in plasma and milk of sheep and in plasma of rabbits.

The data about accuracy, precision and recovery cover the criteria according to other researches (11, 12). The limitations of the method are related to the linearity range between $0.125-1 \mu \mathrm{g} / \mathrm{mL}$ of the standard curve in rabbits' plasma. Pharmacokinetic studies in rabbits showed that maximum plasma concentrations depend on the drug dosage form: doxycycline hyclate solution versus microcapsule suspension (13). After oral administration of doxycycline hyclate at a dose rate $20 \mathrm{mg} / \mathrm{kg}$, higher $\mathrm{C}_{\max }$ were obtained after administration of solution $(1.74 \pm 0.00 \mu \mathrm{g} / \mathrm{ml})$ in comparison to suspension $(1.10 \pm 0.00 \mu \mathrm{g} / \mathrm{ml})$ (13). The rabbits in the cited study were treated with 5 to 8 -fold higher dose than the recommended and widely accepted therapeutic doses of $2.5-4 \mathrm{mg} / \mathrm{kg}$. These data suggest that the accepted dosage regimen would result in much lower concentrations and the linearity range would be wide enough and will allow the determination of plasma concentrations without dilution of the samples. When higher doses are used, plasma samples will need to be diluted. The linearity of the standard curves for ovine plasma from 0.125 to $2.5 \mu \mathrm{g} / \mathrm{mL}$ and for ovine milk from 0.125 to $5.0 \mu \mathrm{g} / \mathrm{mL}$ cover a sufficient range of drug concentrations. The published pharmacokinetic data about doxycycline in ovine plasma indicates that it is broad enough to allow analysis of the concentrations that can be detected after using therapeutic doses of $5-10 \mathrm{mg} / \mathrm{kg}$, but when higher doses of $20 \mathrm{mg} / \mathrm{kg}$ are applied, higher $\mathrm{C}_{\max }$ concentrations of $2.18 \pm 0.95 \mu \mathrm{g} / \mathrm{mL}$ can be expected (14). In these cases, a dilution of the samples will be required. Since the use of doxycycline in lactating animals is prohibited when the milk is used for human consumption, it is not possible to refer the sensitivity of the current method to the quantification of residues in milk.

The recovery rate, LOD, LOQ, intra-, and interassay precision are similar to those reported by other authors $(9,10,13)$. Values of LOD, achieved from the three different matrices, were higher than those of the original method published by Laczay et al. (10). Apart from the different HPLC column used in the cited method, which can be discussed as a reason for lower LOD, the samples were subjected to solidphase extraction. The last technique ensured better clean-up of the sample matrix and concentration of analyte which can explain the higher sensitivity of the validated method for doxycycline determination in the plasma of broiler chickens.

The extraction procedure, described by Lagzay et al. (10) was used after some modification. TFA was applied to precipitate the proteins in samples. As a strong acid, it leads to extreme decreasing of $\mathrm{pH}$ (15) and thus to denaturation and subsequent protein precipitation. In pharmacokinetic studies, it is very important to determinate only the unbound fraction of antibiotics because it is pharmacologically active. It is also important to calculate the dosing regimen on the basis of free antibiotic concentration. MIC are determined in broth and their values represent free drug concentrations. However, in many of the published studies over the years a correction for protein binding had not been done (9). The difference is significant especially when the substance has high protein binding such as doxycycline (16). TFA showed great precipitation efficiency, but still a low amount of bound doxycycline was left after processing of blood samples with the used method of extraction. A mean percentage for correction was calculated in order to be used in future studies. The most substantive adjustments need to be made at the lower concentrations. It is probably due to concentration-dependant protein binding, observed in many other drugs (17). Less free, respectively higher percentage of bound doxycycline was detected at lower concentrations, when equilibrium dialysis of mice plasma was applied (18).

\section{CONCLUSION}

In conclusion, the presented HPLC method with PDA detection can be used in pharmacokinetic studies and future adjustments of dosing regimen. It is simple and fulfills the criteria for accuracy, precision, recovery, and sensitivity. The assay is neither time-consuming, nor expensive. Screening for the presence of doxycycline in ovine plasma and milk, and in rabbit plasma can be performed within a short time by analysis of a single sample. The method allows processing numerous samples per day because of the short run time and simple preparation procedure. A calculation of mean percentage for correction for protein binding was performed and it can be used in future pharmacokinetic studies.

\section{CONFLICT OF INTEREST}

The authors declared that they have no potential conflict of interest with respect to the authorship and/or publication of this article. 
Free doxycycline concentrations in sheep plasma and milk and in rabits' plasma: HPLC method

\section{ACKNOWLEDGEMENTS}

The research was financially supported by Trakia University, Stara Zagora, Bulgaria (Grant № 07/2018).

\section{REFERENCES}

1. Chopra, I., Roberts, M. (2001). Tetracycline antibiotics: Mode of action, applications, molecular biology, and epidemiology of bacterial resistance. Microbiol Mol Biol Rev. 65 (2): 232-260. https://doi.org/10.1128/MMBR.65.2.232-260.2001 PMid:11381101 PMCid:PMC99026

2. Valentín, S., Morales, A., Sánchez, J.L., Rivera, A. (2009). Safety and efficacy of doxycycline in the treatment of rosacea. Clin Cosmet Investig Dermatol. 2, 129-140.

PMid:21436975 PMCid:PMC3047926

3. Agwuh, K. N., MacGowan, A. (2006). Pharmacokinetics and pharmacodynamics of the tetracyclines including glycylcyclines. J Antimicrob Chemother. 58, 256-265. https://doi.org/10.1093/jac/dk1224 PMid:16816396

4. Redelsperger, I. M., Taldone T., Riedel, E. R., Lepherd, M. L., Lipman, N. S., Wolf, F. R. (2016). Stability of doxycycline in feed and water and minimal effective doses in tetracycline - inducible systems. J Am Assoc Lab Anim Sci. 55 (4): 467-474. PMid:27423155 PMCid:PMC4943619

5. Ahmed, M. M., Rahman, M. M., Mahbub, K. R., Wahiduzzaman, M. (2011). Characterization of antibiotic resistant Salmonella spp. isolated from chicken eggs of Dhaka City. J Sci Res. 3 (1): 191-196. https://doi.org/10.3329/jsr.v3i1.6109

6. Naz, S., Hanif, A., Maqbool, A., Ahmed, S., Muhammand, K. (2012). Isolation, characterization and monitoring of antibiotic resistance in Pasteurella multocida isolates from buffalo (Bubalus bubalis) herds around Lahore. J Anim Plant Sci. 22 (3): 242-245.

7. Tejedor-Junco, M. T., González-Martín, M., Bermeo-Garrido, E., Villasana-Loaiza, R., Carretón-Gómez, E. (2018). Doxycycline treatment for Dirofilaria immitis in dogs: impact on Staphylococcus aureus and Enterococcus antimicrobial resistance. Vet Res Commun. 42 (3): 227-232.

https://doi.org/10.1007/s11259-018-9727-z PMid:29938353
8. Maaland, M.G., Papich, M.G., Turnidge, J., Guardabassi, L. (2013). Pharmacodynamics of doxycycline and tetracycline against Staphylococcus pseudintermedius: proposal of canine-specific breakpoints for doxycycline. J Clin Microbiol. 51 (11): 3547-3554.

https://doi.org/10.1128/JCM.01498-13

PMid:23966509 PMCid:PMC3889732

9. Meijer, L. A., Ceyssens, K. G. F., de Greve, B. I. J. A. C., de Bruijn, W. (1993). Pharmacokinetics and bioavailability of doxycycline hyclate after oral administration in calves. Vet Q. 15, 1-5. https://doi.org/10.1080/01652176.1993.9694358

10. Laczay, P., Semjen, G., Lehel, J., Nagy, G. (2001). Pharmacokinetics and bioavailability of doxycycline in fasted and nonfasted broiler chickens. Acta Vet Hung. 49, 31-37.

https://doi.org/10.1556/004.49.2001.1.5

PMid:11402688

11. Shabir, G. A. (2003). Validation of high-performance liquid chromatography methods for pharmaceutical analysis. Understanding the differences and similarities between validation requirements of the US Food and Drug Administration, the US Pharmacopeia and the International Conference on Harmonization. J Chromatogr A. 987, 57-66.

https://doi.org/10.1016/S0021-9673(02)01536-4

12. European Medicines Agency: [Internet]. Guideline on bioanalytical method validation. [cited 2011; last assessed on 09 November 2018].

https://www.ema.europa.eu/documents/scientific-guideline/guideline-bioanalytical-method-validation_en.pdf

13. Fu, H., Zhang, L., Zhang, W. (2011). Preparation of doxycycline hyclate microcapsule and its pharmacokinetic in rabbit. Acta Vet et Zootechnica Sinica. 42 (10): 1438-1444.

14. Castro, L. J., Sahagun, A. M., Diez, M. J., Fernandez, N., Sierra, M., Garcia, J. J. (2009). Pharmacokinetics of doxycycline in sheep after intravenous and oral administration. Vet J. 180, 389-395.

https://doi.org/10.1016/j.tvj1.2008.02.001

PMid:18440843

15. Zellner, M., Winkler, W., Hayden, H., Diestinger, M., Eliasen, M., Gesslbauer, B., et al. (2005). Quantitative validation of different protein precipitation methods in proteome analysis of blood platelets. Electrophoresis 26, 2481-2489. https://doi.org/10.1002/elps.200410262 PMid:15895463 
16. Riond, J.L., Riviere, J.E. (1989). Doxycycline binding to plasma albumin of several species. J Vet Pharmacol Ther. 12 (3): 253-260.

https://doi.org/10.1111/j.1365-2885.1989.tb00668.x PMid:2810474

17. Zeitlinger, M. A., Derendorf, H., Mouton, J. W., Cars, O., Craig, W. A., Andes, D., Theuretzbacher, U. (2011). Protein binding: do we ever learn? Antimicrob Agents Chemother. 55 (7) : 3067-3074. https://doi.org/10.1128/AAC.01433-10

PMid:21537013 PMCid:PMC3122431
18. Chaturvedi P., Esposito, C., Koroma, J., Cannon, E.P., Tanaka, S.K. (2003). In vitro assessment of plasma protein binding and metabolic stability of PTK 0796 (BAY 73-6944). Book of abstracts of the 43th Interscience conference of antimicrobial agents and chemotherapy. F-760, Chicago, USA. 